Chirurgia (2019) 114: 326-330

No. 3, May - June

Copyright $\odot$ Celsius

http://dx.doi.org/10.21614/chirurgia.114.3.326

\title{
Parental Health Literacy in the Pediatric Surgical Setting
}

\author{
Georgios Kampouroglou', Venetia-Sofia Velonaki², Ioanna D. Pavlopoulou², Georgios Fildissis², \\ Konstantinos Tsoumakas ${ }^{2}$
}

'Department of Pediatric Surgery, Aghia Sophia Children's Hospital, Athens, Greece

${ }^{2}$ Department of Nursing, School of Health Sciences, National and Kapodistrian University of Athens, Greece

Corresponding author:

Georgios Kampouroglou, MD

$\mathrm{PhD}$ candidate

Resident in Pediatric Surgery

Department of Pediatric Surgery

Aghia Sophia Children's Hospital

Thivon \& Levadeias, 11527

Athens, Greece

E-mail: gkampouroglou@gmail.com

\section{Rezumat}

\section{Educatia medicală a părintilor în contextul chirurgiei pediatice}

Educația medicală in contextul pediatric a fost asociată cu rezultate medicale scăzute şi joacă un rol important în existența inegalității în acest domeniu. Educația medicală precară a părinților / tutorilor influențează rezultatele medicale, în special în cazul copiilor cu boli cronice. Încercând să identificăm rolul educației medicale în contextul chirurgiei pediatrice şi a stomatologiei, am efectuat o reexaminare a literaturii de specialitate relevante. Puținele studii şi eterogenitatea scăzută a metodologiei nu au dus la rezultate specifice. Nevoia de studii mai extinse în domeniu este evidentă şi esențială pentru ameliorarea calității îngrijirii chirurgicale la copii şi adolescenți.

Cuvinte cheie: educație medicală, pediatrie, părinte, chirurgie.

\section{Abstract}

Health literacy (HL) in the pediatric setting has been associated with poor health outcomes and plays an important role in the existing health disparities. Low parents'/caregivers' HL influences health outcomes mainly in chronically ill children. Trying to identify the role of HL in the pediatric surgical and dentistry setting, we conducted a review of the relevant literature. The paucity of studies and the heterogeneity of the methodology do not lead to specific results. The need for more and larger studies in the field is evident and crucial in order to ameliorate the quality of surgical care in pediatric patients. 
Key words: health literacy, pediatric, parent, surgery

\section{Introduction}

Health literacy (HL) is defined as "the knowledge, motivation and competencies to access, understand, appraise and apply health information in order to make judgments and take decisions in everyday life concerning health care, disease prevention and health promotion to maintain or improve quality of life throughout the course of life" " (1).

Ninety million adults are estimated to have low HL in the United States. Known risk factors include low socioeconomic status, limited English-language proficiency and racial/ethnic minority-group identification (2). HL has been found to be an important contributor to existing health disparities (3).

Nearly $30 \%$ of US caregivers are estimated to have below basic or basic health literacy, which has implications for child health $(2,3)$. In the pediatric emergency department over of $50 \%$ of parents/ caregivers were found to be of low HL status (4). Low HL is more frequent among caregivers of minority race and has been found to affecthealth disparities independently of race, low educational level and socioeconomic status (5).

The relationship of HL to adult health is well documented in the current literature (6). Moreover, the role of caregivers' HL of adult care recipients has been studied, since they can impact the quality of care provided. Associations were found between low caregiver HL and poorer care recipient self-management behaviours, increased use of health services and increased caregiver burden (7).

In the pediatric setting, fewer studies have examined the role of HL for child health (8). Nevertheless, various studies have demonstrated that parental HL is strongly associated with children's health outcomes (poor glycemic control in diabetic children, poor understanding of medication labels, drug dosing errors) (9).

Especially in the pediatric surgical setting, HL of parents/caregivers plays an important role in the preoperative and postoperative period. Important instructions have to be understood and implemented and important decisions to be made $(6,10)$.

\section{Methods}

In this setting, we conducted a literature search to identify studies that evaluate the role of parents'/caregivers' HL in the pediatric surgical setting. We searched the National Library of Medicine's Pubmed database and Google Scholar with the terms "health», "literacy», "parents or caregivers», "pediatric» and "surgery». We also reviewed the reference list from identified studies in order to identify additional ones.

\section{Results}

Five studies were identified addressing directly the subject of parents'/caregivers' HL in the pediatric surgical setting (Table 1).

In the study of Ot al et al. (11) HL of patients attending the pediatric outpatient clinic was evaluated. The main goal of the study was the evaluation of a plain language educational material mailed to parents before the consultation. HL level was found to be related to socioeconomic status and education. Twenty-nine percent presented inadequate HL, probably an underestimate, due to the denial of participation of parents from low socioeconomic level. But this percentage of parents is significant, bearing in mind that in a surgical consultation important information is given concerning planned surgical treatment. In this setting, even the obtained informed consent is of questionable value. In the same study, the plain language educational material was well accepted by parents, regardless of their HL level.

In the study of Yin et al (12) parents of 823 children presenting to an urban public hospital pediatric clinic in New York City 
Table 1. Studies in pediatric surgery and pediatric dentistry related with $\mathrm{HL}$

\begin{tabular}{|c|c|c|c|c|c|c|}
\hline Author & $\begin{array}{l}\text { Year of } \\
\text { the study }\end{array}$ & Specialty & Inadequate $\mathrm{HL}$ & Instrument & Intervention & Outcome \\
\hline Otal et al. & 2012 & Pediatric Surgery & $\begin{array}{l}29 \% \\
\text { (possible underestimate) }\end{array}$ & NVS & none & $\begin{array}{l}\text { Satisfaction with information } \\
\text { (plain languagematerials) }\end{array}$ \\
\hline Dahl et al. & 2015 & $\begin{array}{l}\text { Emergencies } \\
\text { in Pediatric Surgery }\end{array}$ & $\begin{array}{l}\text { English speaking } 30 \% \\
\text { Spanish speaking } 23 \%\end{array}$ & $\begin{array}{l}\text { BASH } \\
\text { (Brief acculturation } \\
\text { scale for Hispanics) }\end{array}$ & none & $\begin{array}{l}\text { Gap in communication during } \\
\text { consent }\end{array}$ \\
\hline Shin et al. & 2013 & Pediatric Dentistry & $\begin{array}{l}\text { Score range from } 7 \text { to } 30 \\
\text { (highest possible) }\end{array}$ & $\begin{array}{l}\text { REALD-30 } \\
\text { (oral } \mathrm{HL} \text { ) }\end{array}$ & none & $\begin{array}{l}\text { Dental anxiety related to } \\
\text { REALD-30 score }\end{array}$ \\
\hline Miller et al. & 2010 & Pediatric Dentistry & $\begin{array}{l}\text { Limited literacy } 55.7 \% \\
\text { (score }<=22 \text { ) }\end{array}$ & $\begin{array}{l}\text { REALD-30 } \\
\text { (oral HL) }\end{array}$ & none & $\begin{array}{l}\text { Caregiver's literacy associated } \\
\text { with children's dental disease } \\
\text { status }\end{array}$ \\
\hline Cegala et al. & 2013 & Pediatric Surgery & Non-defined & S-TOFLA & $\begin{array}{l}\text { Communication } \\
\text { skills intervention }\end{array}$ & $\begin{array}{l}\text { Positive effect of the } \\
\text { intervention on the participation } \\
\text { to the consultation } \\
\text { (HL not related to participation) }\end{array}$ \\
\hline
\end{tabular}

were evaluated concerning their level of HL. Its relationship to perceptions of barriers to care and preferences for clinical decisionmaking were also examined. They concluded that parents with low HL were more likely to perceive difficulties concerning access to care and rely on the doctor's opinions/ proposals as far as decision-making was concerned (12).

This issue has not yet been addressed in a pediatric surgery setting, where the process of decision-making prior to a surgical act is of fundamental importance.

On the contrary, in a pediatric surgery setting, the study from Cegala et al (13), the participation of parents in the surgical consultation was not influenced by their HL level. Significant predictors of parents' participation were consultation length and parents' income.

A communication skills intervention was also performed (booklet mailed before the consultation) which showed that intervention parents participated significantly more than controls to the surgical consultation. So, the authors concluded that providing parents with communication guidelines before a surgical consultation may improve the communication process with possible positive implications for the informed consent.

Concerning emergency medical procedures (lumbar puncture, incision and drainage of abscesses, repair of complex lacerations, excision of an ingrown toenail and fracture reduction) a prospective study among 55 parents was conducted in Phoenix, Arizona, in a low-literacy Latino patient population. Parents of children requiring the above invasive acts in the pediatric emergency department after signing an informed consentwere asked to recall respective elements. English speaking parents and theones with more than high-school education were more likely to recall information from the informed consent than Spanish speaking parents (10).

\section{Pediatric Dentistry}

In the pediatric dentistry setting, the role of parent HL has been relatively more investigated. In a study of Miller et al (14) among 106 caregiver/child dyads who were enrolled, a statistically significant association between caregiver's HL and children's dental disease status was found. More in detail, caregivers of children with mild to moderate treatment needs were found to have higher HL levels than those of children with severe treatment needs (14).

Finally, in the study of Shin et al (15), a very interesting association of parents'/ guardians' 
HL and dental anxiety is examined. The study enrolled 187 parents/ guardians and dental anxiety and oral HL were measured using relevant tools. The findings are very interesting: among socioeconomically disadvantaged patients, contributors to poor oral health are both low dental HL and high dental anxiety. The exact dynamics between anxiety and HL status need to be further investigated, the authors propose (15).

\section{Other Studies/Findings}

In a recent study enrolling 17845 families in the US, low parent HL was found to be independently and significantly related also to at-risk family behaviors associated with child injury (8).

Finally, very interesting are the findings of Morrison et al. who examined the HL of 504 caregivers of children up to 12 years old who presented to the emergency department. They found that children of minority caregivers with low HL received fewer radiologic studies. No difference was found between minority caregivers with adequate HL compared with white caregivers with adequate HL. These results underline the important role of $\mathrm{HL}$ in the disparities in healthcare resource utilisation (16).

\section{Discussion}

The main finding of our review of the literature is the very small number of studies related to HL in the pediatric surgical setting.

The sample sizes are also smaller than relevant studies in the pediatric setting, not to mention the number of patients included in the adult research. This problem is common in surgical specialities, as even in the adult literature concerning surgery and HL the number of studies is also relatively small (6). In the adult setting, a recent systematic review of $\mathrm{HL}$ in the perioperative setting concluded that low HL could be associated with poor adherence to preoperative instructions, problematic understanding of the surgical procedure and of the discharge instructions (6). We propose that HL of parents/guardians should be systematically evaluated in studies concerning disparities in pediatric surgical care and the decisionmaking process preoperatively.

Added to the above, there is heterogeneity among studies concerning the instrument used for the evaluation of HL (Table 1). This fact does not allow direct comparisons between the results of different studiesnor generalisation of outcomes.

No studies were found concerning HL in the setting of pediatric solid organ transplantation. Transplantation as a treatment option is very complex and requires very complicated evaluation processes, difficult decisionmaking and informed consent and follow up medical regimen. In this setting the role of $\mathrm{HL}$ of the family of little patients about to receive transplants is crucial.

Concerning transplantation in pediatric patients and HL of their parents, very little is known (17). We can derive from adult studies, that in an adult kidney transplant centre $41 \%$ of patients had limited HL (18) and many patients presented important gaps in trans ${ }^{-}$ plant knowledge $(19,20)$. It is thus considered important not to forget about HL when dealing with transplantation issues in children to help their families understand the procedures and make the best decisions (17).

The main limitation of the present review is the small number of studies included, not giving the possibility of generalising outcomes.

\section{Conclusion}

There is a remarkable paucity of studies that examine HL of parents/caregivers in the pediatric surgical setting. The problem of inadequate HL plays an important role in healthcare resource utilisation, decisionmaking and understanding of the informed consent process and also seems to influence health-related anxiety, all very important aspects in the setting of pediatric surgical care. 
We conclude that there is a need for additional studies, in order to clarify the impact of HL to the aforementioned parameters and provide guidance for HL-related interventions to eliminate these problems from everyday surgical practice.

\section{Conflict of Interest}

The authors declare that they have no conflict of interest.

\section{References}

1. Sørensen K, Van den Broucke S, Fullam J, Doyle G, Pelikan J, Slonska Z, et al. Health literacy and public health: a systematic review and integration of definitions and models. BMC Public Health. 2012;12:80.

2. Kutner M, Greenberg E, Jin Y, Paulsen C, White S. The Health Literacy of America's Adults: Results From the 2003 National Assessment of Adult Literacy.In: Institute of Medicine (US) Committee on Health Literacy; Nielsen-Bohlman L, Panzer AM, Kindig DA, editors. Washington (DC): National Academies Press (US); 2004.3.

4. Morrison AK, Schapira MM, Gorelick MH, Hoffmann RG, Brousseau DC. Low caregiver health literacy is associated with higher pediatric emergency department use and non-urgent visits. Acad Pediatr 2014;14(3):309-14.

5. Yin HS, Johnson M, Mendelsohn AL, Abrams MA, Sanders LM, Dreyer BP. The health literacy of parents in the United States: a nationally representative study. Pediatrics. 2009;124(suppl 3):S289-S298.

6. De Oliveira GS, McCarthy RJ, Wolf MS, Holl J. The impact of health literacy in the care of surgical patients: a qualitative systematic review. BMC Surg. 2015;15:86.

7. Yuen EY, Knight T, Ricciardelli LA, Burney S. Health literacy of caregivers of adult care recipients: A systematic scoping review.
Health Soc Care Community. 2018;26(2):e191-e206. Epub 2016 Jul 18.

8. Cheng ER, Bauer NS, Downs SM, Sanders LM. Parent Health Literacy, Depression, and Risk for Pediatric Injury. Pediatrics. 2016;138(1):e20160025

9. Howe CJ, Winterhalter E. Parent Health Literacy: Risks and Outcomes. J Pediatr Nurs. 2013;28(5):515-6.

10. Dahl A, Sinha M, Rosenberg D, Tran M, Valdez A. Assessing Physician-Parent Communication During emergency Medical Procedures in Children. An observational Study in a Low-Literacy Latino Population. Pediatr Emer Care 2015;31(5):339-42.

11. Otal D, Wizowski L, Pemberton J, Nagel K, Fitzgerald P, Walton MJ. Parent health literacy and satisfaction with plain language education materials in a pediatric surgery outpatient clinic: a pilot study. J Pediatr Surg. 2012;47(5):964-9.

12. Yin SH, Dreyer BP, Vivar KL, MacFarland, Schaick L, Mendelsohn AL. Perceived Barriers to Care and Attitudes Towards Shared Decision-making Among Low Socioeconomic Status Parents:Role of Health Literacy. Acad Pediatr. 2012:12(2):117-24.

13. Cegala DJ, Chisolm DJ, Nwomeh BC. A communication skills intervention for parents of pediatric surgery patients. Patient Educ Couns. 2013;93(1):34-9.

14. Miller E, Lee JY, DeWalt DA, Vann WF. Impact of Caregiver Literacy on Children's Oral Health Outcomes. Pediatrics. 2010;126(1): 107-14.

15. Shin WK, Braun TM, Inglehart MR. Parents' dental anxiety and oral health literacy: effects on parents' and children's oral healthrelated experiences. J Public Health Dent. 2014;74:195-201.

16. Morrisson AK, Brousseau DC, Brazauskas R, Levas MN. Health Literacy affects likelihood of radiology testing in the Pediatric Emergency Department. J Pediatr 2015;166(4):1037-41.

17. Shellmer D, Brosig C, Wray J. The start of the transplant journey: Referral for pediatric solid organ transplantation. Pediatr Transpl. 2014;18(2):125-33.

18. Escobedo $E$, Weismuller $P$. Assessing health literacy in renal failure and kidney transplant patients.Progr Transplant. 2013;23(1): 47-54.

19. Gordon E, Wolf M. Health literacy skills of kidney transplant recipients. Prog Transplant. 2009;19(1):25-34.

20. Kauffman HM, Woodle ES, Cole W, Paykin C. Transplant recipient's knowledge of posttransplantmalignancy risk: implications for educational programs. Transplantation. 2008;85(7): 928-33. 